\title{
Essay
}

\section{The Emergence of Feminist Jurisprudence: An Essay}

\author{
Ann C. Scales†
}

A hand or something passes across the sun. Your eyeballs slacken, you are free for a moment. Then it comes back: this test of the capacity to keep in focus

this

unfair struggle with the forces of perception ${ }^{1}$

We as lawyers have been trained to desire abstract, universal, objective solutions to social ills, in the form of legal rules or doctrine. Much of the history of feminist ${ }^{2}$ jurisprudence has reflected that tradition. It has been

$\dagger$ Professor of Law, University of New Mexico Law School. B.A. 1974, Wellesley College; J.D. 1978, Harvard Law School. This essay is derived from the inaugural lecture in the Dean's Lecture Series, Yale Law School, on April 15, 1985. Thanks to the persons connected with that event, particularly Dean Guido Calabresi, Associate Dean Jamienne Studley, and Ellen-Liebman. The text has been expanded and footnotes added with the assistance of Jane Marx.

1. A. Rich, $A$ Vision (Thinking of Simone Weil), in A Wild Patience Has Taken ME This FAR 50 (1981).

2. I do not mean to confine "feminism" to a way of thinking available only to persons born female. Rather, I refer to feminism as a method, as the critique of objectivity in epistemological, psychological, and social-as well as legal-terms. Similarly, when I refer to "femaleness," "maleness," or ascribe "points of view" to either sex, I am relying on the premise that gender identity is a complex, socially-determined phenomenon, a process (unavoidable to its subjects) of conscription into rigid sex roles. Thus, the male and female "points of view" surely vary among individuals, but are demonstrably "sex-linked" with respect to the rites of genderization.

Nor do I mean to suggest that feminism is a monolithic movement. I have no wish to underplay our diversity; on the contrary, I welcome it. Our divergence in opinion, widely advertised as a weakness by opponents of the Equal Rights Amendment in the 1970's, has proved to be a source of great strength. The debate over pornography, for example, is intense and seems far from resolution. Yet that controversy has produced remarkable legal theories, see, e.g., MacKinnon, Not a Moral Issue, 2 YALE L. \& POL'Y REv. 321 (1984) (defending Indianapolis pornography ordinance in terms of failures of assumptions underlying First Amendment doctrine), revitalized debate about the First Amendment (and hence, about the role of government); Emerson, Pornography and the First Amendment: A Reply to Professor MacKinnon, 3 Yale L. \& PoL'y Rev. 130 (1985) (rehabilitating First Amendment doctrine), and involved the courts in exactly the sort of public discourse which is vital to society. 
a debate, in the abstract, about appropriate rules. This essay uses the work of several non-legal authors ${ }^{3}$ to illustrate the impossibility of seeing solutions to inequality through that lens of abstraction. This essay concerns feminist efforts to live with, and ultimately to resist, abstraction itself. It is also an essay about the power of the way things are: how comfortably we respond in accord with our learned reticence; how easily we leap for shallow solutions; and how such solutions are shifting shadows, constantly testing our capacity to keep in focus, keeping us in fear of being blinded by a brighter light.

\section{WHERE WE'VE BEEN}

In this country, the engine of the struggle for equality has been Aristotelian: Equality means to treat like persons alike, and unlike persons unlike. ${ }^{4}$ Under this model, when legal distinctions are made, the responsible sovereign must point to some difference between subjects which justifies their disparate treatment. ${ }^{5}$ That was the model in Reed $v$. Reed ${ }^{6}$ the first equal protection case decided favorably in the Supreme Court for women. Under the expert guidance of Ruth Bader Ginsburg and the ACLU Women's Rights Project, the Reed Court held that the state of Idaho could not presumptively deny to women the right to administer estates. With respect to such activities, the Court saw that women and men are "similarly situated." That is, no demonstrable difference between the sexes justified treating them differently.

This is what Professor Catharine MacKinnon has called "the differences approach,"8 and it worked extraordinarily well for Ginsburg and her legions. Indeed, all was going swimmingly until the Court had to face situations where the sexes are not, or do not seem to be, similarly situ-

See American Booksellers Assoc. v. Hudnut, 771 F.2d 323 (7th Cir. 1985) (Indianapolis ordinance defining pornography as subordination of women violates First Amendment), affd, 106 S. Ct. 1172 (1986).

3. Focusing primarily upon the work of Ludwig Wittgenstein, Carol Gilligan, Dorothy Dinnerstein, and Adrienne Rich, I arrive at an endorsement of Catharine MacKinnon's radical feminist legal theory. The use of Wittgenstein will surprise some, but is a necessary choice for me. Without prior exposure to Wittgenstein, I would probably have been trapped by legal education into believing the paeans to objectivity which are the target of my criticism.

4. Aristotle, Nichomachean Ethics V(3), at 112-14 (D. Ross trans. 1925).

5. This is what Charles Frankel has called "basic equality." Frankel, Equality of Opportunity, 81 ETHICs 191, 194-96 (1971). As Frankel points out, the fact that the sovereign must justify its actions is an advance over Aristotelian formal equality, where any perceived difference produces difference in treatment. "Basic equality" is ultimately unsatisfying, however, because the rule that reasons must exist does not indicate how good those reasons have to be. Id.

6. 404 U.S. 71 (1971).

7. Id.

8. C. Mackinnon, Sexual Harassment of Working Women 101 (1979) (emphasis omitted). 
ated-situations involving pregnancy, ${ }^{9}$ situations involving the supposed overpowering sexual allure which women present to men, ${ }^{10}$ and situations involving the historical absence of women. ${ }^{11}$ When the "differences approach" was applied in those cases, the plaintiffs lost. Aristotle would have been thrilled.

Feminist legal scholars have devoted enormous energies to patching the cracks in the differences approach. The debate has been, and continues to be, arduous. ${ }^{12}$ Which differences between the sexes are or should be relevant for legal purposes? How does one tell what the differences are? Does it matter whether the differences are inherent or the result of upbringing? Is it enough to distinguish between accurate and inaccurate stereotyped differences? Or are there situations where differences are sufficiently "real" and permanent to demand social accommodation?

In response to these questions, feminists have tried to describe for the judiciary a theory of "special rights" for women which will "fit"13 the discrete, non-stereotypical, "real" differences between the sexes. ${ }^{14}$ And

9. Geduldig v. Aiello, 417 U.S. 484 (1974) (exclusion of pregnancy from risks covered by state employees' insurance plan does not constitute sex discrimination under equal protection clause). For a fuller if not altogether convincing treatment of the pregnancy issue, see Scales, Towards a Feminist Jurisprudence, 56 IND. L.J. 375 (1981) (arguing that the law provides no "special rights," but only enforces the guarantee of equality, by taking pregnancy and breastfeeding explicitly into account).

10. For an analysis of how the image of "woman as temptress" excuses discrimination, see Aiken, Differentiating Sex from Sex: The Male Irresistible Imprulse, 7 N.Y.U. REV. L. \& Soc. CHANGE 357 (1984). Most illustrative of this phenomenon are Dothard v. Rawlinson, 433 U.S. 321 (1977) (refusal to hire female prison guards allowed under Title VII as bona fide occupational qualification), and Michael M. v. Sonoma County Super. Ct., 450 U.S. 464 (1981) (constitutionality of California's statutory rape law sustained). The Court in Michael $M$. relied upon the asserted statutory purpose of preventing pregnancy: Because only women can become pregnant, young males need an additional incentive for responsibility, namely, the fear of prosecution. Id. at 473 . The history of that 1850 statute suggests, however, that its real purpose was to preserve the chastity of young females. See Williams, The Equality Crisis: Some Reflections on Culture, Courts, and Feminism, 7 Women's RTS. L. REP. 175, 181 n.47 (1982).

11. Rostker v. Goldberg, 453 U.S. 57 (1981) (upholding constitutionality of exclusion of women from draft registration). For the reverse side of this familiar coin, see Personnel Adm'r v. Feeney, 442 U.S. 256 (1979) (upholding Massachusetts veterans' preference for civil service positions).

12. I jumped into it wholeheartedly. See Scales, supra note 9. Some notable examples in this debate are C. MacKinnon, supra note 8; E. Wolgast, EQUALITY AND THE Rights of Women (1980); Krieger \& Cooney, The Miller-Wohl Controversy: Equal Treatment, Positive Action and the Meaning of Women's Equality, 13 GoLdEN GATE L. REv. 513 (1983); Law, Rethinking Sex and the Constitution, 132 U. PA. L. REv. 955 (1984); Wasserstrom, Racism, Sexism, and Preferential Treatment: An Approach to the Topics, 24 UCLA L. REv. 581 (1977); Williams, supra note 10; Note, Toward a Redefinition of Sexual Equality, 95 HARv. L. REv. 487 (1982).

13. The "fit" metaphor probably had its origin in Tussman \& tenBroek, The Equal Protection of the Laws, 37 CALIF. L. REv. 341 (1949), and is usually presented in terms of the famous Venn diagrams therein. Id. at 347. The "fit," of course, is an important elaboration upon the constitutional requirement of functional justification as first articulated by Chief Justice John Marshall in McCullough v. Maryland, 17 U.S. (4 Wheat.) 316 (1819): "Let the end be legitimate, . . . and all means which are appropriate, which are plainly adapted to that end, . . . are constitutional." Id. at 421.

14. The articles cited in note 12, for example, operate within the "equal rights/special rights" arena (with the dramatic exception of MacKinnon). Feminist battled feminist over "equal rights" versus "special rights" regarding a Montana statute which requires employers to grant maternity, but not paternity, leave to employees. MONr. CODE ANN. § 49-2-310 (1983) (formerly § 39-7-203 
here lies our mistake: We have let the debate become narrowed by accepting as correct those questions which seek to arrive at a definitive list of differences. In so doing, we have adopted the vocabulary, as well as the epistemology and political theory, of the law as it is.

When we try to arrive at a definitive list of differences, even in sophisticated ways, we only encourage the law's tendency to act upon a frozen slice of reality. In so doing, we participate in the underlying problem-the objectification of women. Through our conscientious listing, we help to define real gender issues out of existence. Our aim must be to affirm differences as emergent and infinite. We must seek a legal system that works and, at the same time, makes differences a cause for celebration, not classification.

A new jurisprudence emerges as we cease to conduct the debate in prescribed legalistic terms. The equal/special rights debate, for example, reflects the circularity of liberal legal thinking. The rights formula, described in terms of constitutional fit, presumes a fixed reality of gender to which law must conform. The problem of sexual inequality, however, when understood as systematic domination, is not susceptible to that view. Our past reliance on rights/rule structuring has been disappointing, ${ }^{15}$ because we have been unable to see the solipsism of the male norm. Our tendency as lawyers to seek comprehensive rules in accordance with that norm is a dangerous learned reflex which defeats feminism's critique of objectification.

\section{The Tyranny of Objectivity}

[M]ale dominance is perhaps the most pervasive and tenacious system of power in history . . . it is metaphysically nearly perfect. Its point of view is the standard for point-of-viewlessness; its particularity the meaning of universality. Its force is exercised as consent, its

(1981)). For a description of the legislative hearings, see Williams, supra note 10 , at 194-95. The statute was upheld on the ground that it put women and men on more equal terms. Miller-Wohl Co. v. Commissioner of Labor and Indus., 515 F. Supp. 1264, 1266 (D. Mont. 1981), appeal dismissed, 685 F.2d 1088 (9th Cir. 1982); Miller-Wohl Co. v. Commissioner of Labor \& Industry, 692 P.2d 1243, 1254 (Mont. 1984).

15. For women, rules have historically been rather like the Maginot line. American constitutional rules have delivered much less than expected, from the Nineteenth Amendment to the "intermediate standard" of equal protection review. See, e.g., Graig v. Boren, 429 U.S. 190 (1976) (establishing heightened "middle-tier" of scrutiny in gender discrimination actions); $c f$. Rostker v. Goldberg, 453 U.S. 57 (1981) (exclusion of women from draft registration satisfies middle-tier, in spite of overwhelming evidence in favor of inclusion). I will not rehash that history, because I wish to resist the sense of obligation felt by many feminist legal writers to reinvent the wheel (just as I did, see Scales, supra note 9, at 377-422). Our tendency to do that indulges the solipsism of the patriarchal legal system. Because, by its standards, inequality is hard to perceive, we obligingly keep starting from scratch to make it perceptible. Instead, we must challenge the "objective" standards which objectify us, which make us invisible and our history unimportant. 
authority as participation, its supremacy as the paradigm of order, its control as the definition of legitimacy. ${ }^{16}$

Underlying the Supreme Court's ruling in Reed $v$. Reed ${ }^{17}$ was a perception that sexism is a distortion of reality. Once the Court made this discovery, it needed to transform its discovery into a legalistic code, to construct an "objective" rule. And here lies the most difficult part of rulemaking in our system as it is-phrasing the rule so that people believe that the rule is detached, so that it appears to transcend the results in particular cases. $^{18}$

The philosophical basis of such an approach is "abstract universality." "I9 In order to apply a rule neutrally in future cases, one must discern $a$ priori what the differences and similarities among groups are. But because there are an infinite number of differences and similarities among groups, one must also discern which differences are relevant. To make this determination, one must first abstract the essential and universal similarities among humans; ${ }^{20}$ one must have strict assumptions about human nature as such. Without such an abstraction, there is no way to talk about which differences in treatment are arbitrary and which are justified. Underlying this approach is the correspondence theory of truth: The sovereign's judgments are valid only when they reflect objective facts. ${ }^{21}$ Thus, somewhere in the nature of things there must be a list of sex differences that matter and those that do not. Notice, however, that abstract universality by its own terms cannot arrive at such a list. It has no "bridge to the concrete"22 by which to ascertain the emerging and cultural qualities which constitute difference.

With nothing above ground, abstract universality constructed a dark tunnel to its tainted delusion. It made maleness the norm of what is human, and did so sub rosa, all in the name of neutrality. ${ }^{23}$ By this sub-

16. MacKinnon, Feminism, Marxism, Method, and the State: Toward Feminist Jurisprudence, 8 Signs 635, 638 (1983) (footnotes omitted) [hereinafter cited as Mackinnon, Toward Feminist Jurisprudence]. This article was the sequel to MacKinnon, Feminism, Marxism, Method, and the State: An Agenda for Theory, 7 Signs 515 (1982) [hercinafter cited as MacKinnon, An Agenda for Theory].

17. 404 U.S. 71 (1971).

18. The quality of transcendence of results has been said to be the primary feature of neutrality in constitutional adjudication. Wechsler, Toward Neutral Principles of Constitutional Law, 73 HARV. L. REv. 1, 12 (1959).

19. Gould, The Woman Question: Philosophy of Liberation and the Liberation of Philosophy, in Women and Philosophy: Toward A Theory of Liberation 5-6 (C. Gould \& M. Wartofsky eds. 1976).

20. Id. at 13.

21. For a fuller explanation of correspondence, see B. Russel.l, The Problems of Philosophy 126-30 (1959).

22. Gould, supra note 19 , at 20.

23. The most striking example is Justice Bradley's concurrence in Bradwell v. Illinois, 83 U.S. (16 Wall.) 130, 14-42 (1872) (holding 14th Amendment's privileges and immunities clause did not 
terranean system, the "relevant" differences have been and always will be those which keep women in their place. ${ }^{24}$ Abstract universality is ideology, pure and simple. It is a conception of the world which takes "the part for the whole, the particular for the universal and essential, or the present for the eternal."28 With the allegedly anonymous picture of humanity reflecting a picture males have painted of themselves, women are but male subjectivity glorified, objectified, elevated to the status of reality. The values of things "out there" are made to appear as if they were qualities of the things themselves. So goes the process of objectification: the winner is he who makes his world seem necessary. ${ }^{28}$

Feminist analysis begins with the principle that objective reality is a myth. It recognizes that patriarchal myths are projections of the male psyche. $^{27}$ The most pernicious of these myths is that the domination of women is a natural right, a mere reflection of the biological family. ${ }^{28}$ The

entitle Myra Bradwell to bar membership):

[T]he civil law, as well as nature herself, has always recognized a wide difference in the respective spheres and destinies of man and woman. Man is, or should be, a woman's protector and defender. The natural and proper timidity and delicacy which belongs to the female sex evidently unfits it for many of the occupations of civil life. The constitution of the family organization, which is founded in the divine ordinance, as well as in the nature of things, indicates the domestic sphere as that which properly belongs to the domain and functions of womanhood .... The paramount destiny and mission of woman [sic] are to fulfill the noble and benign offices of wife and mother. This is the law of the Creator. And the rules of civil society must be adapted to the general constitution of things....

24. The cataloguing of differences along the lines described in the text is most evident in the pregnancy area, where the treatment of pregnancy demanded by women would impose an immediate financial burden on men. See, e.g., General Electric Co. v. Gilbert, 429 U.S. 125 (1976). That case rejected a Title VII challenge to an employer's refusal to include pregnancy in its disability benefits program. The Supreme Court stated: "Title VII's proscription on discrimination does not . . . require the employer to pay that incremental amount. The District Court was wrong in assuming, as it did, that Title VII's ban on employment discrimination necessarily means that 'greater economic benefit[s]' must be required to be paid to one sex or the other because of their differing roles in 'the scheme of human existence." "Id. at 139 n.17 (citations omitted).

The economic argument, however, papers over the higher stakes. If pregnancy were treated as those petitioners demanded, women's roles in society would be very different; they would cease to lead a bifurcated existence. Scales, supra note 9, at 387-88, 435-37. In terms of the present analysis, if pregnancy were treated without reference to a male norm, women would cease to wear the most important trappings of "the other."

25. Gould, supra note 19 , at 21.

26. As MacKinnon puts it:

Combining, like any form of power, legitimation with force, male power extends beneath the representation of reality to its construction: it makes women (as it were) and so verifies (makes true) who women "are" in its view, simultaneously confirming its way of being and its vision of truth. ... Objectivity is the methodological stance of which objectification is the social process. Sexual objectification is the primary process of subjection of women. It unites act with word, construction with expression, perception with enforcement, myth with reality.

MacKinnon, An Agenda for Theory, supra note 16, at 539, 541.

27. Smith, The Sword and Shield of Persens: Some Mythological Dimensions of the Law, 6 J.L. \& Psychintry 235, 239 (1983).

28. Id. at $240-41$. Smith demonstrates that biology has always served as the link between the "natural order" and the normative social order. He cites G.B.A. Coker, who in his study of primitive legal systems stated that "almost every known legal concept began and ended with the family." G. Coker, Family Property Among the Yorubas (2d ed. 1966), cited in Smith, supra note 27, at 
patriarchal paradigm of the will of the father informs rationality at every historical stage. Professor J.C. Smith points out how that paradigm, centrally driven by a need to subjugate woman and all that is womanly, is violently reflected in the myth of Perseus. Perseus was able to slay the female monster Medusa, but only with the goddess Athena guiding his hand. Whereas Medusa was the archetype of a free woman, Athena was the patriarchal stereotype of women, reflecting male needs. Because Athena was not of woman born, she was always for her father's side: She was an avowed servant of patriarchy. ${ }^{20}$

With the advent of the Golden Age, Greek thinkers rejected the Olympian ideal and embraced natural laws susceptible of mathematical formulation. When all that irrationality gave way to objectivity, it would seem that the Greeks could have begun to take equality seriously in civic life. But they never did free their slaves or emancipate their women. Objectivity left them plenty of room for immoral discretion, and they chose a political structure that ensured the survival of male privilege. ${ }^{30}$ With the Olympian mythic structure displaced, however, privilege had to be justified some other way, for detached justification is the mechanism of domination. The master must be able to describe the relationship as good in itself (as Olympian-decreed hierarchy seemed good), in order to get the slave to exhibit the regularities being used to justify the relationship. ${ }^{31}$ That is the hegemonic method of patriarchy: its aims are united within a social fabric by assimilating the subordinated classes into the dominant one, and by allying those classes with it. ${ }^{\mathbf{3 2}}$

Plato and Aristotle were hegemonic heroes, not only for their own times but as models for the future. Their declarations of woman as partial $\operatorname{man}^{33}$ have been the prototype for all neo-mythic justifications of domination, from Christianity to Freud, through social darwinism, and including economic and scientific explanations of the social order. ${ }^{34}$ The narcotic influence which objectivity has increasingly exerted over our minds makes us ever less alert to the mythic structure around us. ${ }^{35}$

238 n.4.

29. Id. at $260-61$.

30. Id. at $252-54$.

31. Harding, Is Gender a Variable in Conceptions of Reality? A Survey of Issues, in BEYOND Domination: New Perspectives on Women and Philosophy 44-45 (G. Gould ed. 1984).

32. See A. Gramsct, Selections From the Prison Notebooks of Antonio Gramsci 181-82, 195-96, 246-50 (Q. Hoare \& G. Smith trans. \& eds. 1971) (discussing dominant groups in general).

33. For a helpful synopsis of early theories about the nature of woman, see Whitbeck, Theories of Sex Difference, in Women and Phinosophy: Toward a Theory of Liberation 54 (C. Gould \& M. Wartofsky eds. 1976).

34. See Smith, supra note 27 , at 255-60.

35. "While the myth has become secularized and framed in the language of scientific inquiry, it is still a projection of the male psyche where 'nature' or the natural evolutionary process has been 
A legal system must attempt to assure fairness. Fairness must have reference to real human predicaments. Abstract universality is a convenient device for some philosophical pursuits, or for any endeavor whose means can stand without ends, but it is particularly unsuited for law. Law is, after all, a social tool. It is only extrinsically important. Its actual value depends upon its success in promoting that which is intrinsically valuable. By inquiring into the mythic structure of objectivity, we see that abstract universality explicitly contradicts the ideal of a "government of laws, not men." Our task, therefore, is to construct a system which avoids solipsism, which recognizes that the subjectivity of the law-maker is not the whole of reality.

\section{A Gall for Vigilance}

It is imperative for jurisprudence to tap the power of the more radical versions of feminism. An effective contemporary feminist critique must be radical in the literal sense. It must go to the root of inequality. Without extraordinary subterranean vigilance, the radical potential of feminism will be undermined. Like other movements that presage revolutionary change, feminism faces a constant threat of deradicalization.

In her popular book, In A Different Voice, ${ }^{38}$ developmental psychologist Carol Gilligan observed that little girls and little boys appear to grapple with moral problems differently. ${ }^{37}$ Boys tend to make moral decisions in a legalistic way: they presume that the autonomy of individuals is the paramount value, and then employ a rule-like mechanism to decide among the "rights" of those individuals. ${ }^{38}$ Gilligan refers to this as the "ethic of rights"s9 or the "ethic of justice." ${ }^{40}$ Girls, on the other hand, seem to pro-

substituted for a heavenly creating father." Smith, supra note 27, at 245; see also Harding, supra note 31 , at 48 .

36. C. Gilligan, In A Different Voice (1982).

37. Gilligan does not claim to be making generalizations about either sex or about the origins of the differences observed. Id. at 2 . Her book is about modes of problem-solving which happen in her research to correspond, albeit incompletely, to gender categories. For us to worry about the lack of fit between her observations and those gender groups is to fall back into the fallacy of the "equal rights/ special rights" debate. We must resist the pressure to decide, abstractly and irrevocably, what the differences between the sexes might be. For present purposes, I would use Gilligan's results for two working hypotheses. First, given what I have experienced as the expectations imposed upon growing up female, I am always surprised to observe women who do not tend toward conformity to a simplified Gilligan-esque model. The same holds true for my experience with male decision-makers. Thus, insofar as law reflects the "rights-based" part of that model, it would seem disproportionately to have excluded women's point of view from participation in its creation and administration. Second, given "objectivity" as the systemic criterion for the validity of decisions, the mode of reasoning associated with femaleness does not and cannot count. Thus, more than mere incorporation of that "female" voice is required.

38. Gilligan, supra note 36 , at 25-51.

39. Id. at 164 .

40. Id. at 174 . 
ceed by the "ethic of care."11 They have as their goal the preservation of the relationships involved in a given situation. ${ }^{42}$ Their reasoning looks like equity: they expand the available universe of facts, rules, and relationships in order to find a unique solution to each unique problem. . $^{4}$

Just as Gilligan's work has the potential to inspire us in historic ways, ${ }^{44}$ it could also become the Uncle Tom's Cabin of our century. Lawyers are tempted to use Gilligan's work in a shallow way, to distill it into a neat formula. Her thesis is memorable, handy, and easy to oversimplify. Rightly or wrongly, many people feel that such an oversimplified version comports with their experience of the sexes. Moreover, generalizations taken from Gilligan provide accessible analogues to the law/equity split, and to the ethical positions competing in any legal dispute. All in all, Gilligan's work tempts one to suggest that the different voices of women can somehow be grafted onto our right- and rule-based legal system. ${ }^{45}$

One in a non-vigilant mode might be moved to think that we could have a system which in the abstract satisfies all the competing considerations: rules, rights, relationships, and equity. This is what I call the "incorporationist" view. ${ }^{48}$ Gilligan asserts that as a matter of personal moral development, the ability to integrate the ethics of care with the ethics of.rights signals maturity. ${ }^{47}$ I think no one would disagree with such a goal in an emotional realm. Emotional and cognitive maturity have, however, come to mean very different things. ${ }^{18}$ In the majority culture, emotional maturity does not count as knowledge. The ad hoc evaluations we must under41. Id. at 164.
42. Id. at 29.
43. Id.
44. It has already helped support some excellent work in the area of alternative dispute resolu-
tion. See, e.g., Menkel-Meadow, Toward Another View of Legal Negotiation: The Structure of Prob-
lem Solving, 31 UCLA L. REv. 754,763 n.28 (1984) (Gilligan's theory supports argument that
problem-solving, as opposed to adversarial, negotiation is preferable).

45. See, e.g., Karst, Woman's Constitution, 1984 DuKE L.J. 447, 484, 494-95 (urging that legal system should open up to "the voices of women").

46. "Incorporationism" is the label I gave to the approach that I supported in 1981. See Scales supra note 9, at 435 . Though not identical to the view that I criticize here, my stance had the same basic flaw-an obsession with what differences between men and women the law could, in the abstract, take into account. Pregnancy and breastfeeding, I thought, had to be accounted for if the law were to take a sufficiently broad view of equality: Equality requires that a woman not be forced to choose between children and career, just as a man need not make that choice. I endorse my former view thus far. I then believed also that only pregnancy and breastfeeding could be taken into account, because those were the only two "objectively" determinable differences between the sexes. The law, I believed, needed to steer completely clear of the "subjective" phenomenon of stereotyping. I now see that limitation as unnecessarily reticent and guaranteed to achieve nothing, as many such liberal assumptions are.

47. C. Giluigan, supra note 36, at 151-74. Gilligan admits that the contours of such an integration are difficult to envision clearly, id. at 165, because the perspectives are "opposite truths," "two different moral ideologies." Id. at 164.

48. E. Keller, Reflections On Gender and Science 84 (1985). 
take in the emotional realm cannot be acknowledged elsewhere. Such judgments are not "reliable;" only "objectivity" is reliable. We should be especially wary when we hear lawyers, addicted to cognitive objectivity as they are, assert that women's voices have a place in the existing system. In the words of James Agee: "Official acceptance is the one unmistakable symptom that salvation is beaten again, and is the one surest sign of fatal misunderstanding, and is the kiss of Judas." 49

Incorporationism presumes that we can whip the problem of social inequality by adding yet another prong to the already multi-pronged legal tests my students feel they must memorize. Incorporationism suffers from the same lack of vision as the "equal rights/special rights" debate. Both presume that male supremacy is simply a random collection of irrationalities in an otherwise rational co-existence. Both presume that instances of inequality are mere legal mistakes-a series of failures to treat equals as equals which we can fix if we can just spot the irrationality in enough cases. ${ }^{30}$ As Professor MacKinnon has demonstrated, however, from such viewpoints we cannot see that male supremacy is a complete social system for the advantage of one sex over another. ${ }^{51}$ The injustice of sexism is not irrationality; it is domination. Law must focus on the latter, and that focus cannot be achieved through a formal lens. Binding ourselves to rules would help us only if sexism were a legal error.

A commitment to equality requires that we undertake to investigate the genderization of the world, leaving nothing untouched. The principles of objectivity, abstraction, and personal autonomy are at risk. In our search, we must look for the deeper causes and consequences of Gilligan's findings. Her work is empirical evidence for what feminist theory has already postulated: A male point of view focuses narrowly on autonomy, on the separation between self and others. ${ }^{52}$ That disjunction contains the roots of domination. In the terms of feminist theory, male reality manifests itself by negating that which is non-male. The male model defines self, and other important concepts, by opposing the concept to a negativized "other." Male rationality divides the world between all that is good and

49. J. Agee \& W. Evans, Let Us Now Praise Famous Men 15 (1941). My colleague Karl Johnson and $I$, in a required first year jurisprudence course, use these words to admonish caution in our students as they begin their search for authority in law. For further description of (and discussion with other scholars about) teaching jurisprudence in the first year, see Johnson \& Scales, An Absolutely, Positively True Story, 16 N.M.L. Rev. (forthcoming 1986).

50. See C. MACKInNON, supra note 8 , at 102.

51. Id. at 121 .

52. Gilligan would say, I think, that the typical development of the male pysche focuses first on autonomy, and only later on relationships. See C. Gil.LIGAN, supra note 36, at 160-64 (discussing male psyche).

53. These ideas were first articulated in a feminist context by Simone de Beauvoir. S. DE Beauvoir, The Second Sex (H. Parshley trans. 1952). 
all that is bad-between objective and subjective, light and shadow, man and woman. For all of these dichotomies (and there are scores more), the goodness of the good side is defined by what it is not.

Whereas the male self/other ontology seems to be oppositional, the female version seems to be relational. ${ }^{\text {s4 }}$ The female ontology is an alternative theory of differentiation that does not define by negation nor require a "life and death struggle"ss to identify value in the world. Instead, it perceives relationship as constitutive of the self. It perceives dichotomization as irrational..$^{\mathbf{6}}$

Male and female perceptions of value are not shared, and are perhaps not even perceptible to each other. ${ }^{57}$ In our current genderized realm, therefore, the "rights-based" and "care-based" ethics cannot be blended. Patriarchal psychology sees value as differently distributed between men and women: Men are rational, women are not. Feminist psychology suggests different conceptions of value: Women are entirely rational, but society cannot accommodate them because the male standard has defined into oblivion any version of rationality but its own. ${ }^{\mathbf{8}}$ Paradigmatic male values, like objectivity, are defined as exclusive, identified by their presumed opposites. Those values cannot be content with multiplicity; they create the other and then devour it. Objectivity ignores context; reason is the opposite of emotion; rights preclude care. As long as the ruling ideology is a function of this dichotomization, incorporationism threatens to be mere co-optation, a more subtle version of female invisibility.

By trying to make everything too nice, incorporationism represses contradictions. It usurps women's language in order to further define the world in the male image; it thus deprives women of the power of naming. ${ }^{59}$ Incorporationism means to give over the world, because it means to

54. The term "self/other ontology" and the distinction between "relational" and "oppositional" ontologies are taken from Whitbeck, A Different Reality: Feminist Ontology, in BEYOND Dominstion: New Perspectives on Women and Philosophy 64 (C. Gould ed. 1984).

55. Id. at 69.

56. Id. at 76 .

57. "My research suggests that men and women may speak different languages that they assume are the same, using similar words to encode disparate experiences of self and social relationships. Because these languages share an overlapping moral vocabulary, they contain a propensity for systematic mistranslation . . . C. Gilligan, supra note 36, at 173.

58. See Harding, supra note 31 , at 52 .

59. "Naming" is a critical concept to feminism. When we discover what we really think and express it, we give words and the world new meaning. And when we call each other's names, we affirm a core of our being as women that we are only now unlearning to devalue. But this feminist "naming" should not be confused with nominalism nor with a reference theory of meaning. For us "Naming' is a political term. "Naming" means rejecting the Adam myth that the world was made for males to discern; it means reclaiming our own world and our own experiences. Virginia Woolf describes this process in A Room of One's Own. V. WoOlf, A RoOM OF ONE's OwN 31-38 (1957). She describes how at first she was surprised at men's hatred toward women, then she became angry about it, and then:

[B]y degrees fear and bitterness modified themselves into pity and toleration; and then in a 
say to those in power: "We will use your language and we will let you interpret it."

There are words I cannot choose again: humanism androgyny

Such words have no shame in them, no diffidence

before the raging stoic grandmothers:

their glint is too shallow, like a dye

that does not permeate

the fibers of actual life

as we live it, now ... ${ }^{60}$

\section{FEMINIST METHOD}

To question everything. To remember what it has been forbidden even to mention. To come together telling our stories, to look afresh at, and then to describe for ourselves, the frescoes of the Ice Age, the nudes of "high art," the Minoan seals and figurines, the moonlandscape embossed with the booted print of a male foot, the microscopic virus, the scarred and tortured body of the planet Earth. ${ }^{61}$

Feminist thinking has evolved dramatically in the last twenty years, from an essentially liberal attack on the absence of women in the public world to a radical vision of the transformation of that world. ${ }^{62}$ The demand for "gender neutrality" which served valiantly in the legal struggles of the seventies has inevitably become a critique of neutrality itself, which

year or two, pity and toleration went, and the greatess release of all came, which is freedom to think of things in themselves. That building, for example, do I like it or not? Is that picture beautiful or not? Is that in my opinion a good book or a bad? Indeed [having a room of my own] unveiled the sky to me, and substituted for the large and imposing figure of a gentleman, which Milton recommended for my perpetual adoration, a view of the open sky.

Id. at 39.

60. A. Rich, Natural Resources, in The Dream of a Common Language: Poems 1974-1977, at 66 (1978). As she puts the same sentiment in prose:

The urge to leap across feminism to "human liberation" is a tragic and dangerous mistake. It deflects us from our real sources of vision, recycles us back into old definitions and structures, and continues to serve the purposes of patriarchy, which will use "women's lib," as it contemptuously phrases it, only to buy more time for itself-as both capitalism and socialism are now doing. Feminism is a criticism and subversion of all patriarchal thought and institutions-not merely those currently seen as reactionary and tyrannical.

A. Rich, Toward a Woman-Centered University, in ON LIES, SECRETS, ANd Silence: Selected Prose 1966-1978, at 134 n.11 (1979) (emphasis in original).

61. A. Rich, Forward: On History, Illiteracy, Passivity, Violence, and Women's Culture, in ON Lies, SeCrets, ANd Silence: Selected Prose 1966-1978, at 13-14 (1979).

62. For a demonstration of the feminist theoretical revolution in the context of the "hard" sciences, see E. KELLER, supra note 48, at 75-94. 
proceeds by an admittedly non-neutral method. Explanations of our method usually provoke the charge of nominalism, such is the staying power of the ideal of objectivity. Feminist method would appear to be an easy target for that weapon. Feminism does not claim to be objective, because objectivity is the basis for inequality. Feminism is not abstract, because abstraction when institutionalized shields the status quo from critique. Feminism is result-oriented. It is vitally concerned with the oblivion fostered by lawyers' belief that process is what matters.

The next step for theory is therefore to demonstrate that feminist method leads to principled adjudication and a more orderly coexistence. Let us begin by reconsidering Carol Gilligan's results. The little boys' approach divides life into opposing camps. In a moral dilemma, this person or that person shall win, based upon some "essential" difference in their situations. One must be shown to be unworthy and wrong. One must be transformed into the "other."

Perhaps there is something in the paradigm of male infant development which teaches a harsh method of differentiation. Insofar as objectification is taught as the preferred way to see the world, we replicate the emotional substructure of domination. The children are thereby programmed, prepared to fall into the habit of objectification which is at the heart of woman-loathing. As adults, these people may have noble intentions, but it will be too late. At best, they will become incorporationists-people who must co-opt the voices of the powerless, who can't let them speak for themselves because, by definition, "the other" is mute. ${ }^{63}$

Compare the problem-solving method used by the little girls. Their habit of expanding the context, of following the connections among people and events, is descriptive of rationality. When given a situation with which to grapple, the girls do not insist upon uncovering an essence of the problem, but look rather for a solution that is coherent with the rest of experience.

If I am right that the "rights-based" and "care-based" approaches are incompatible, we must make a choice between adjudicative principles. The choice is not, however, between male and female hegemony. The choice is rather between a compulsion to control reality and a commitment to restrain hegemony. ${ }^{64}$ Do we want a system that brooks no disagreement or

63. Dorothy Dinnerstein argues, for example, that the radical male's attempts to overcome oppression are inevitably abortive:

He is drawing strength from the subservience of woman for a struggle against the tyranny of man; but he can keep woman subservient only with the strength he draws from the sponsorship of the male tyrant.

D. Dinnerstein, The Mermaid and The Minotaur 196 (1977).

64. See E. KELLER, supra note 48, at 178 ("A healthy science is one that allows for the productive survival of diverse conceptions of mind and nature, and of correspondingly diverse strategies. In 
one that invites as many points of view as the varieties of existence require? The values of honesty and pragmatism require us to choose the relational model, because only it describes how we as language-users actually and responsibly perform according to truly meaningful criteria. ${ }^{65}$

Consider Wittgenstein's explanation of the concept of "games." concept we all use with great success, but what is its "essence?" There isn't one.

[L]ook and see whether there is anything common to all [games]. For if you look at them you will not see something that is common to all, but similarities, relationships, and a whole series of them at that. To repeat: don't think, but look! ${ }^{67}$

Investigation of the world is a matter of communication, and communication can never be made out of context. How we use any concept, whether it be "game" or "domination," cannot depend on some universal essence. By looking around, we have examples-we can grasp the concept. Then we recognize other examples, not because they share any essence, but because of their relational matrix.

[W]e extend our concept . . . as in spinning a thread we twist fibre on fibre. And the strength of the thread does not reside in the fact that some one fibre runs through its whole length, but in the overlapping of many fibres. ${ }^{68}$

Law, like the language which is its medium, is a system of classification. To characterize similarities and differences among situations is a key step in legal judgments. That step, however, is not a mechanistic manipu-

my vision of science, it is not the taming of nature that is sought, but the taming of hegemony.").

65.

The well-regulated clock keeps good time and the well-drilled circus seal performs its tricks flawlessly, yet we do not call them 'intelligent'. We reserve this title for the persons responsible for their performances. To be intelligent is not merely to satisfy criteria, but to apply them; to regulate one's actions and not merely to be well-regulated. . . . [A person] applies criteria in performing critically, that is, in trying to get things right.

G. Ryle, The CONCEPT OF Mind 28-29 (1963).

66. L. Wittgenstein, Philosophical Investigations \$\$ 66-78, at 31-36 (G. Anscombe trans. 3d ed. 1968). I do not mean to imply that I think of the process of legal justification as a game. On the contrary, it is misleading when legal philosophers do, see, e.g., Rawls, Two Concepts of Rules, 64 PHIL. REv. 3, 24-27 (1955) (comparing adjudication to baseball), because legal proceedings often require us to question the rules themselves as well as what the rules mean. Wittgenstein's point, I take it, is that when we use even a very familiar concept (like "games"), we are making a complex but reliable judgment by means of criteria we cannot even articulate.

67. L. WITTGENSTEIN, supra note $66, \S 66$, at 31 .

68. Id. $\S 67$, at 32 . It is fitting that, for this example and the next, Wittgenstein talks about activities that are traditionally relegated to women: spinning thread and child tending. 
lation of essences. Rather, that step always has a moral crux. Consider another Wittgensteinian example:

Someone says to me: "Shew the children a game." I teach them gaming with dice, and the other says "I didn't mean that sort of game." Must the exclusion of the game with dice have come before his mind when he gave me the order? ${ }^{68}$

Imagine this as a legal problem. Shall we indict Wittgenstein for corrupting minors or not? Perhaps he simply made a mistake about what he was supposed to do. It was just a lapse in communication. Or it could be that Wittgenstein had the requisite intent; perhaps he is a lover of corruption. In the first case, shall we say that Wittgenstein was mistaken about the essence of the command, or in the second, that he violated the essence of the command? As the last sentence of the quote implies, the order-giver didn't think about the possibility that Wittgenstein would choose dice when the order was given. The essence of the thing does not exist. Our decision does not depend upon whether "dice" falls within the statutory term, nor upon any objectively determinable similarity or difference between this game and others. It depends upon a larger context which is not neutral at all.

Law needs some theory of differentiation. Feminism, as a theory of differentiation, is particularly well suited to it. Feminism brings law back to its purpose-to decide the moral crux of the matter in real human situations. Law is a complex system of communication; its communicative matrix is intended to give access to the moral crux. Finding the crux depends upon the relation among things, not upon their opposition. In any case, imperfect analogies are available; a case is similar or dissimilar to others in an unlimited variety of ways. The scope and limits of any analogy must be explored in each case, with social reality as our guide. ${ }^{70}$ This is a normative, but not illogical process. Any logic is a norm, ${ }^{71}$ and cannot be used except with reference to its purposes. Why should that be so hard to perceive, to teach, and to do?

Wittgenstein believed that his work with language was obvious, that he was supplying "observations which no one has doubted, but which have escaped remark only because they are always before our eyes." 72 It would also seem obvious that relational reasoning is law's soul, that law's duty is to enhance, rather than to ignore, the rich diversity of life. Yet this purpose is not obvious; it is obscured by the myth of objectivity which opens

69. Id. at 33 (note without section number).

70. Whitbeck, supra note 54 , at 75-76.

71. Harding, supra note 31 , at 57 .

72. L. WITtGenSTEIN, supra note $66, \S 415$, at 125. 
up law's destructive potential. Feminism inverts the logical primacy of rule over facts. Feminist method stresses that the mechanisms of law-language, rules, and categories-are all merely means for economy in thought and communication. They make it possible for us to implement justice without reinventing every wheel at every turn. But we must not let means turn into ends. When those mechanisms obscure our vision of the ends of law, they must be revised or ignored. Sometimes we must take the long route in order to get to where we really need to be.

In feminist thought, deciding what differences are relevant for any purpose does not require objectifying and destroying some "other." Feminism rejects "abstract universality" in favor of "concrete universality." The former conjures differences-it elevates some to dispositive principles and defines others out of existence-and makes maleness the norm. The latter reinterprets differences in three crucial ways. First, concrete universalism takes differences to be constitutive of the universal itself. Second, it sees differences as systematically related to each other, and to other relations, such as exploited and exploiter. Third, it regards differences as emergent, as always changing. ${ }^{73}$

In the past, two legal choices appeared to resolve claims of social injustice: Law could either ignore differences, thereby risking needless conformity, or it could freeze differences, thereby creating a menu of justifications for inequality. Concrete universality eliminates the need for such a choice. When our priority is to understand differences and to value multiplicity, we need only to discern between occasions of respect and occasions of oppression. Those are judgments we know how to make, even without a four-part test to tell us, for every future circumstance, what constitutes domination.

Only let us understand what "inexact" means. For it does not mean "unusable"."74

One might say that the concept 'game' is a concept with blurred edges.-"But is a blurred concept a concept at all?"-Is an indistinct photograph a picture of a person at all? Is it even always an advantage to replace an indistinct picture by a sharp one? Isn't the indistinct one often exactly what we need? ${ }^{75}$

A precise picture of a fuzzy scene is a fuzzy picture. Domination comes in many forms. Its mechanisms are so insidious and so powerful that we could never codify its "essence." The description that uses no formula, but which points to the moral crux of the matter, is exactly what we need.

73. Gould, supra note 19 , at 27.

74. L. WITTGENSTEIN, supra note $66, \S 88$, at 41.

75. L. WITTGENSTEIN, supra note $66, \S 71$, at 34 . 
Feminist Jurisprudence

\section{Psychoanalytic Frameworks}

The goal of discerning domination requires that the law recognize the psychological substructures of gender. The legal system recoils from this prescription on the ground that judgments about human development are beyond its ken, that the law's point-of-viewlessness would be sullied by such inquiries. This predictable response, however, is the reason for the psychoanalytic inquiry in the first place. Feminist method discloses that the law has "a personal investment . . . in impersonality."76 Psychoanalytic theory helps us to understand why the legal system has insisted upon its lack of subjectivity and to analyze the subjectivity that so loudly denies its presence. Though logically incoherent, the "I'm not here" position conforms to prior emotional experience; it is "stamped by the interpersonal drama through which it was learned." law can best be seen as an excessive response to "the long and painful process by which the child's sense of self is formed." objectivity is the cognitive counterpart to the individual's anxiety about autonomy. Both objectivity and autonomy demand that an individual be "severed from the outside world of other objects. . . and simultaneously from [his] own subjectivity." we must learn to control if we are to halt our species' ever more determined efforts to destroy itself. ${ }^{81}$

Feminist jurisprudence is unique in its demand for an adequate psychology. Feminist jurisprudence goes beyond liberalism in requiring legal decision-makers to reexamine any doctrine that is justified by an ethic of individual autonomy. The liberal humanist goal of protecting the "untrammelled exercise of capacities central to human rationality"82 not only does not apply to disenabled persons, but often requires the systematic deprivation of the freedom of others. ${ }^{83}$ In making the connection between

76. E. KELLLER, supra note 48 , at 10.

77. Id. at 71 .

78. Id. at 80 .

79. Id. at 70

80. Id. at 91 n.6.

81. Dorothy Dinnerstein has most urgently drawn the connection between infant development and self-destruction: "our steady growth toward a more open-eyed, foresightful awareness of [our] selfcreative process will have been the essence of our species' life while it lasted, the core of its impulse to know itself and live itself out." D. DinNERSTEIN, supra note 63, at 12 n."

82. Richards, Free Speech and Obscenity Law: Toward a Moral Theory of the First Amendment, 123 U. PA. L. REv. 45, 62 (1974). This liberal humanist rhetoric depends upon the oppositional self/ other ontology. As Richards makes clear: "these liberties are fundamental conditions of the integrity and competence of a person in mastering his life and expressing this mastery to others." Id. at 82 .

83. As MacKinnon says regarding pornography: "To liberals, speech must never be sacrificed for other social goals. But liberalism has never understood that the free speech of men silences the free speech of women." MacKinnon, supra note 2, at 337 (footnote omitted). See generally id. at 335-39 (challenging assumptions underlying First Amendment doctrine). 
domination and mechanisms of sex-role differentiation, feminism also goes beyond Marxism. The latter sees domination as imposed by external economic and political factors; feminism attends fully to the powerful oppressive forces within us. ${ }^{84}$ The social experiences of the sexes are not the same; a social theory without a convincing psychological account of that differentiation cannot remedy gender inequality.

So, as Freud would say, what do women want? Though Freud was miles away from seeing the significance of his question, he did contribute an insight fundamental to feminism: Humans are not wholly rational animals. There are weird things going on in there. Our viewpoints are informed by irrational, sometimes morbid patterns. ${ }^{85}$ Feminism recognizes within us that which Freud saw as irrational, and asserts, therefore, that when dealing with social inequality there are no neutral principles. We are dealing rather with the most pervasive implications of diseased unconscious. But Feminism rejects what Dorothy Dinnerstein has shown to be Freud's essentially conservative belief that our defects constitute a fixed condition of the species' existence. ${ }^{\mathbf{8 b}}$ Freud's conclusions about us are a contingent rationalization, but his psychoanalytic model is an invaluable description of the process of conscription into socially-determined sexroles. ${ }^{87}$

In one neo-Freudian account, Dinnerstein describes the process by which infants become dependent upon, and then learn to loathe, women. We are not Athene. We are woman-born, and almost without exception, we are woman-nurtured in our infancy. It is to a woman we turn in our helplessness; it is a woman who gives us our first grief when we discover that she is imperfect and not always available; it is a woman who, by her imperfection and her omnipotence, introduces us to existential angst. Thus, Dinnerstein explains, our social arrangements reflect the necessity of renouncing our first love while at the same time living out our anger at her. ${ }^{88}$

The males of the species have been able to do this by dichotomizing the world, by separating out man from woman, society from nature, enter-

84. MacKinnon, An Agenda For Theory, supra note 16, at 520. "To the extent that materialism is scientific it posits and refers to a reality outside thought which it considers to have an objective-that is, truly nonsocially perspectival-content. Consciousness raising, by contrast, inquires into an intrinsically social situation, into that mixture of thought and materiality which is women's sexuality in the most generic sense." Id. at 543.

85. See N. Brown, Life Against Death: The Psychoanalytic Meaning of History 1-10 (1959).

86. D. Dinnerstein, supra note 63 , at xii.

87. Rubin, The Traffic in Women, in Feminist Frameworks: Alternative Theoretical Accounts of the Relations Between Women and MEN 154 (A. Jaggar \& P. Struhl eds. 1978).

88. D. DinNerstein, supra note 63 , at 33-34, 91-114. 
prise from homeyness, history from love. ${ }^{89}$ By this process, we inherited a society built around what Aldous Huxley called "organized lovelessness." 90 The enterprise of making history is tinged with residual anger at mother, and can be only a partial consolation for the loss of intimacy. ${ }^{91}$ The enterprise becomes a "compulsive concentration on what can be predicted, controlled, manipulated, possessed and preserved, piled up and counted."92 As should be clear from that description, it is an enterprise reflected, enhanced, and often directed by the legal system.

To this familiar account Dinnerstein adds an analysis of the symbiotic nature of sexual pathology. She argues that both sexes, at least in their stereotypical, genderized roles, have a stake in "keeping history mad." woman acting in a genderized role-as nurturer, worrier, and lamenter-may have no say in decisions of historical importance, but she does get benefits: she gains the approval of those who are powerful, and, of course, she does not have to take responsibility for making ugly historical decisions. ${ }^{94} \mathrm{~A}$ man acting in a genderized role-as warrior, as historymaker, and as keeper of woman-avoids moral responsibility for his actions and need not admit the ugliness of aggressive behavior. He has women there to ventilate the difficult emotions. Women do the weeping for the world, while the mad megamachine rolls on.95

Dinnerstein reveals something crucial about incorporationism: In its simplistic view of the alternative ontologies, incorporationism perpetuates a destructive symbiosis. The rights-based side of things, for all its grand abstraction, describes a pretty grim view of life on the planet. It treats individuals in society as isolated monads, as natural adversaries who must each stake out his own territory and protect it with the sword/shield mechanisms called "rights." This model of aggression is half of what is required for holocaust. False glorification of the "care-based" ethic supplies the other side of the suicidal equation, because a death march requires willing-looking victims. The incorporationist version of the carebased ethic celebrates oblivion. Its Disney-movie appeal diverts attention from the issue of powerlessness, and, indeed, makes a political virtue of it. Masters glorify the contentment of their slaves, empires of their colonies. Here, hegemony strikes again. An incorporationist legal regime would, at

89. See id. at 129-30.

90. A. Huxley, The Perennial Philosophy 93 (1944).

91. See D. Dinnerstein, supra note 63 , at 190.

92. Id. at 135 .

93. Id. at $225-28$.

94. Id. at 211-14. As Dinnerstein acknowledges, Simone de Beauvoir thoroughly explored this theme of female cowardice in the context of existentialist ethics in The Second Sex. Id. (referring to $S$. DE BEAUVOIR, supra note 53).

95. D. Dinnerstein, supra note 63 , at 214-24. 
best, merely institutionalize a familiar female critique-steady but ineffectual..$^{98}$

Dinnerstein's theory flounders, is itself incorporationist, because she looks at the role of women from a patriarchally sanctioned place. She presupposes the ontology which also served Freud so well: the opposition of self and other, the "either/or 'investment' of libidinal energy." Dinnerstein suggests, for example, that patriarchy is possible because, to infants, male authority is an attractive refuge from female authority. "For this reason he is perceived from the beginning . . . as a more human being than the mother, more like an adult version of oneself, less engulfing, less nebulously overwhelming." as women are responsible for infant care, the need to possess and then reject the "dirty goddess" chology. ${ }^{100}$ It seems just as reasonable, however, to view the advent of adult male authority as a set-up. If it's true that daddy looks good compared to mommy, that's a function of the awful way mommy is made to look-irrational, powerless, ingratiating.

Being on the bottom of a hierarchy is not a pose, it is not a choice, there is nothing safe about it, and it only looks brave and defiant to those for whom its choicelessness and violation and dead-ended chances look romantic and elevated because they are not real. ${ }^{101}$

What the Freudians describe is a life and death struggle in infancy, a necessary choosing of sides resulting in sex roles and arrangements. But that conclusion could represent just another way to avoid facing how power is used and abused. The Oedipus and Electra complexes which "explain" the struggle are just as implausible as they always sounded. ${ }^{102}$ As contemporary critics are suggesting, those theories may be suspect cre-

96. Id. at 225-27.

97. Whitbeck, supra note 54 , at 72 .

98. D. DinNERSTEIN, supra note 63 , at 175 (emphasis in original).

99. Id. at 127-34.

100. This analysis leads Dinnerstein to prescribe complete co-responsibility for infant care. Id. at 155. Even in those ever numerically diminishing nuclear families where such a solution would be possible, it is simply not enough. As long as differentiation is a violent concept, it seems that with coresponsibility, daddy would also take on that terrible, mystical quality, and we could learn to loathe both parents equally.

101. MacKinnon, Reply to Miller, Acker and Barry, Johnson, West, and Gardiner, 10 SiGNs 184, 187 (1984).

102. Dinnerstein suggests, for example, that the intimate experience with mother gives rise to a later need in males for exclusive access to a woman. A similar need does not arise in females, however, because female children are themselves internally possessed of that magical quality which made mommy so wonderful in the first place. D. DinNERSTEIN, supra note 63, at 41-43. As Adrienne Rich points out, such an explanation has a rather mystical (and in her view, sinister) ring to it. Rich, Compulsory Heterosexuality and Lesbian Existence, in Powers OF Desire: The Polirics of SEXUALITY 177, 182-83 (A. Snitow, C. Stansell \& S. Thompson eds. 1983). 
ations of Freud's imagination. ${ }^{103}$ Perhaps those ideas were the result of Freud's own inability to deal with the reality of domination: consistent reports from his female patients of sexual molestation. ${ }^{104}$ Feminism requires the law to question the inevitability of sex differentiation, ${ }^{105}$ and to be ever conscious of its role in enforcing female loyalty to men. ${ }^{108} \mathrm{We}$ must look for that which we have been trained not to see. We must identify the invisible, and take responsibility for the violence built into the genderized world.

It is insane at the end of the twentieth century to adhere to the belief that people are innately horrid and can not do better. Rather, we must recognize that our fears-of contingency, ${ }^{107}$ of dependency, ${ }^{108}$ of unimportance ${ }^{108}$ - have put us on a suicidal path. We need now to embrace the lesson of Darwin-that we are a self-creating species. The life and death struggle is now. This is the moment in history when guidance is most needed. Unless the law awakens from its nineteenth century slumber, it condemns itself, at best, to utter irrelevance and, at worst, to complicity in destruction.

\section{CoPING WITH EQUALTTY}

The problem of inequality of the sexes stands in complex relation to the problem of survival. Inequality in the sexual division of labor assures replication of the model of aggression. Pathological aggression accounts for inequality. If these connections are ever to be unpacked, if we are serious

103. Those suggestions became a heated public controversy with the publication of $\mathrm{J}$. MAsson,

The Assault on Truth: Freud's Suppression of the Seduction Theory (1984).

104. For a concise account of Freud's rejection of the seduction theory in favor of the Oedipus complex, see Smith, Gods and Goddesses of the Quadrant: Some Further Thoughts on the Mythological Dimensions of the Law, 7 J.L. \& Psychiatry 219, 222-24 (1985).

105. As Adrienne Rich insists, feminist developmental psychology must ask new questions. Why doesn't the infantile search lead both sexes to women? Why should women ever redirect their search? Why are emotional/crotic relationships so rigidly identified? Why have violent strictures been necessary to keep women in line? Rich, supra note 102, at 182-83.

106. J.C. Smith has produced a helpful list of historical practices, many of which are legally sanctioned, which have evinced the basic psychoanalytic hate-and-control attitude towards women. Smith, supra note 27, at 246-49.

107. See, e.g., J. LACAN, ÉcRIrs: A Selection (A. Sheridan trans. 1977) (describing how males overcome fear of contingency by imposition of "phallocentric" order on world).

108. For the legal repercussions of a psychology of dependency (as opposed to a psychology of aggression), see Smith, supra note 27 , at 241-42.

109. Virginia Woolf speaks of the fear of unimportance in a typically disarming way:

Life for both sexes-and 1 looked at them, shouldering their way along the pavement-is arduous, difficult, a perpetual struggle. It calls for gigantic courage and strength. More than anything, perhaps, creatures of illusion as we are, it calls for confidence in oneself. . . . And how can we generate this imponderable quality, which is yet so invaluable, most quickly? By thinking that other people are inferior to oneself. . . . Women have served all these centuries as looking-glasses possessing the magic and delicious power of reflecting the figure of man at twice its natural size. Without that power probably the earth would still be swamp and jungle. V. Woolf, supra note 59 , at 35 . 
about survival, we need a radically more serious approach to equality. Law must embrace a version of equality that focuses on the real issues-domination, disadvantage and disempowerment-instead of on the interminable and diseased issue of differences between the sexes. I endorse the definition of equality proposed by Professor MacKinnon in 1979: The test in any challenge 110 should be "whether the policy or practice in question integrally contributes to the maintenance of an underclass or a deprived position because of gender status."111 MacKinnon contrasts this to the "differences approach," calling it the "inequality approach."112 I would call the former "thinking like a lawyer;" the latter, "thinking like a person."

That is not to say that the proposed standard will be easy to implement. It will require us to bring the very best of our humanness to bear. That is a scary proposition. No data yet exist to reassure us on the standard's reliability, and, by its own terms, results cannot be predicted without the compilation of records very different from those underlying previously decided cases. The critics appropriately worry, for example, that classifications designed to address the real problems of women (such as pregnancy legislation) will serve to reinforce stereotypes about women's place. ${ }^{113}$ The problem for feminist legal scholars, I think, is that we are unsure how to measure what about stereotyping is at issue in a given case. The notion of stereotyping connotes over-simplification, inattention to individual characteristics, lack of seriousness, and invariance. We use the concept of stereotyping without difficulty when the challenged practice is based upon an untrue generalization. All of the connotations of stereotyping are clearly implicated in negative ways. In such cases, both the differences approach and the inequality approach would prohibit the classification.

The inequality approach focuses upon two other sources of feminist discomfort: first, the need for a reliable approach to generalizations which are largely true (either because of biology or because of highly successful socialization); and second, the need to distinguish between beneficial and burdensome legislation.

Only the inequality approach attempts to reckon with true generalizations. Indeed, in that view, different treatment based upon unique physical characteristics would be "among the first to trigger suspicion and scru-

110. The standard proposed would apply both to challenges under the equal protection clause and those pursuant to Title VII of the Civil Rights Act of 1964, 42 U.S.C. \$2000e (1982). The examples referred to in this section, therefore, draw from both contexts.

111. C. MACKinnon, supra note 8, at 117 . Nearly identical standards could be applied to other historically disadvantaged groups.

112. Id. at 102.

113. See Williams, supra note 10, at 197-200; Taub, Book Review, 80 ColuM. L. Rev. 1686, 1682-93 (1980) (reviewing C. MacKinnoN, supra note 8). 
tiny." "I14 In the past, biological differences have been used to show that classifications are not sex-based. ${ }^{115}$ Thereby, the reasons for having antidiscrimination laws have been seen as the reasons to allow discrimination. ${ }^{116}$ The inequality approach unravels the tautology. It makes no sense to say that equality is guaranteed only when the sexes are already equal. The issue is not freedom to be treated without regard to sex; the issue is freedom from systematic subordination because of sex..$^{\mathbf{1 1 7}}$

The inequality approach would also reach stereotypes which, though not biologically based, have largely made themselves true through a history of inequality. ${ }^{118}$ Consider the situation in Phillips v. Martin Marietta Corp., ${ }^{119}$ where the company hired males with preschool age children, but would not hire women in that category. As a variation, suppose the trial court had found that women with small children did in fact have greater responsibilities, and therefore were, as a group, less well suited for the jobs in question. Such a finding would correspond to the facts of allocation of child-raising responsibility. ${ }^{120}$ The only challenge that will work in this scenario is one from an "exceptional" woman candidate for employment-a woman with preschool aged children whose job performance will not be impaired by her obligations to them. ${ }^{121}$ The policy will be deemed irrational as applied to her.

Compare the inequality approach, which is triggered not by irrationality, but by disadvantage. In our scenario, the inequality approach is superior because it reaches the worse injustice: The fact that women who fit the stereotype are precluded from advancement in our economic system: A challenge adjudicated by that standard would succeed on behalf of the unexceptional as well as the exceptional. Employers (and other employees

114. See C. MacKinnon, supra note 8 , at 118 (emphasis in original).

115. See, e.g., Michael M. v. Sonoma County Super. Ct., 450 U.S. 464, 476 (1981) (upholding statutory rape law that presumes male is culpable aggressor because "consequences of sexual intercourse and pregnancy fall more heavily on the female than on the male"); Geduldig v. Aiello, 417 U.S. 484, 496 n.20 (1974) (disability insurance system did not "exclude anyone from benefit eligibility because of gender but merely removes one physical condition-pregnancy-from the list of compensable disabilities").

116. See C. MAcKinnon, supra note 8, at 227.

117. See id. at 117 .

118. See id. at 122-25.

119. 400 U.S. 542 (1971) (per curiam) (reversing court of appeals' determination that policy was not sex-based). I am indebted to Professor MacKinnon for the example. C. MacKInNon, supra note 8, at 225-26.

120. The Supreme Court in Phillips did suggest that, on remand, it might be determined that maleness was a bona fide occupational qualification under Title VII. 400 U.S. at 544.

121. If the policy were found not to fall within the narrow ambit of the bona fide occupational qualification (bfoq) exception under $\$ 703(\mathrm{c})$ of Title VII, the company might be forced to apply the criterion sex-neutrally (i.e., both men and women with young children may have the jobs). Then, however, women would still be disproportionately disadvantaged because of the age-old double burden. If the plaintiff challenged the policy on grounds of disproportionate impact, it may be justified as a "business necessity." See Griggs v. Duke Power Co., 401 U.S. 424, 431 (1971). 
who have carried a disproportionately lower burden in child-rearing) would then essentially have to compensate for the benefits they have derived from women's double burden. Such payment should include damages, and court-ordered advancement, day care, parents' leave, and reallocation of workers' hours and rewards. ${ }^{122}$ This redistribution of historical burdens and benefits may seem a sweeping remedy, but it is the only one which addresses the reality. ${ }^{123}$

With respect to our second problem, the discernment of genuinely beneficial classifications, suppose that the same company offered a hiring preference for women with school age children, and provided some relief from the double burden. The offer undoubtedly "reinforces a stereotype," but what shall we make of the fact that the stereotype is in large part-if only contingently and temporarily-true? But true only because women carry a disproportionate burden of the child-caring responsibility in our society. Especially when women can elect to receive the benefits (as opposed to risking stigmatization by them), what is the objection to such a plan? Disadvantage has a way of replicating and reinforcing itself. To oppose the scheme is to be reduced to relying upon a groundswell of exceptional behaviors within the disadvantaged group itself. Historically, however, disadvantaged groups have been forced to rely upon surrogates to better themselves. ${ }^{124}$ That has not required that the groups thus assisted conform for all time to the surrogates' perceptions of them (or even to their own perceptions of themselves).

Beneficial classifications, therefore, seem necessary to the ultimate undoing of stubborn stereotypes. It is true that in our history, stereotypical differences, both real and imagined, have served primarily as convenient, "natural" justifications for imposition of burdens. It does not follow, however, that we cannot use differences progressively. Injustice does not flow directly from recognizing differences; injustice results when those differences are transformed into social and economic deprivation. ${ }^{125}$ Our task then, is to exercise our capacity for discernment in more precise ways. Allegedly beneficial classifications, even when they invoke a stereotype, must be measured against what is objectionable in stereotyping. Beneficial classifications, such as the employment preference in our example, will survive under the inequality approach if they do not have those character-

122. For a discussion of reforms needed by women in the workplace, see Scales, supra note 9, at 437-42.

123. See C. MacKinnon, supra note 8, at 122-27.

124. Ratification of the Nineteenth Amendment, for example, could not have been accomplished without surrogate action. One might plausibly surmise that ratification proceeded from the (partially true) stereotype that women were loyal to men and would not use the vote in ways destructive to male power.

125. See C. Mackinnon, supra note 8 , at 105, 117-18. 
istics. Insofar as the employment preference over-simplifies, it is an oversimplification in the service of a profound complexity, as is any welldrafted policy. The preference provides to individuals the opportunity to demonstrate their capacities when the stereotype is set aside. It evinces laudable seriousness toward the problem, especially insofar as the stereotyper takes upon itself some of the burden of the past discrimination. Last, and perhaps most important, it is not invariant. By definition it points to the stereotype for the purpose of undoing it, as an example of how revised present arrangements can relieve centuries of disadvantage. When allegedly beneficial classifications do not have this form, ${ }^{126}$ or when once beneficial schemes cease to have it, the inequality approach would prohibit them.

Admittedly, the inequality approach would sometimes require that different standards be used for men and women. ${ }^{127}$ If that were not so, however, the approach would not be working. Its emphasis is upon enforced inferiority, not sex-differentiated treatment. ${ }^{128}$ When the aim is to discover the reality of domination, the standard to be applied depends upon the context. The inequality approach requires an investigation which must delve as deeply as circumstances demand into whether the challenged policy or practice exploits gender status. To worry in the abstract about which standard should be applied at what time is to replicate the fallacy of the differences approach.

In short, the inequality approach means that we have to think more broadly about what we want "equality" to mean. The traditional bases for differentiation between the sexes are socially-created categories, given meaning only by assigned biases. We create the relevant comparisons, and are free to do so de novo in light of social realities. Thus, in the preferential hiring situation, we would say that the right at stake, rather than the right to be treated without regard to sex, is the right not to have one's existence bifurcated because of sex. In the pregnancy situation, it is the right to have one's total health needs taken as seriously as are those of the other sex. ${ }^{129}$

126. Professor Taub criticizes MacKinnon for a lack of clarity about Michael M. v. Sonoma County Super. Ct., 453 U.S. 57 (1981), suggesting that MacKinnon does not really have a position on how that case should have come out. Taub, supra note 113, at 1691. Unless I am mistaken about the inequality approach, however, it would surely condemn the California statutory rape provision. The statute could not be seen as "an attempt to offer special protection to prevent women's continued oppression," $i d$., because the reality is that such statutes are designed, first, to render females incapable of consent (thereby institutionalizing their non-personhood), and second, to preserve the chastity of females (thereby preventing property damage). See generally Williams, supra note 10 , at 182-88 (discussing cultural bias underlying adoption of statutory rape laws); Aiken, supra note 10, at 373-75 (portraying statutory rape laws as means to enforce women's fear of male sexuality).

127. See Taub, supra note 113 , at $1690-91$.

128. See C. MAcKinnon, supra note 8, at 115 .

129. To redefine equality in the way suggested is "to treat women as equals by respecting the 
Logic is no obstacle to the implementation of the inequality approach. The obstacles are, rather, perception and commitment. When the fact of judicial manipulation has been so salient in the past, why should we now expect those responsible for implementing the law to be able to see, in any given situation, how women have been disadvantaged ${ }^{130}$ Accustomed as judges are to looking for similarities and differences, they can not or will not make the assessments of deprivation and disempowerment.

My response to this, on optimistic days, is that we are more persuasive than we believe we are. If judges are supposed to accept guidance, we as practitioners and scholars ought to be able to provide it. There has been some progress, however modest. ${ }^{131}$ Our duty is to be vigilant in assuring that what happens is real progress, and to guide the courts through our proposed transformation of adjudication. Four members of the current Supreme Court, for example, seem prepared to listen to a well-reasoned alternative to the plethora of superstructure which plagues constitutional law. ${ }^{132}$ The entire Court cries for guidance as to what differences among us mean. ${ }^{133} \mathrm{I}$ believe we are up to the task.

At less optimistic moments, candor would compel me to admit that implementation of a feminist approach will ultimately depend upon significant changes in judicial personnel. Given what we have experienced, however, I feel comfortable with such an admission. It is time that feminist lawyers spoke openly about the politics of neutrality, instead of pretending that sexism were a legal mistake. We have, for example, squandered over a decade discussing what legal standard could have prevented the outrage of Geduldig v. Aiello. ${ }^{134}$ But let's face it-the problem in that "analysis"

female gender and by ceasing to impose upon women a bifurcated existence; it is . . . to restore to women the opportunity to live a continuous life, integrated with respect to career and procreation just as are the lives of men." Scales, supra note 9 , at 435 .

130. See Taub, supra note 113 , at $1690-91$; Williams, supra note 10 , at 196 .

131. Taub cites Califano v. Goldfarb, 430 U.S. 199 (1977), as an example of the Court's inability to see disadvantage to women. Taub, supra note 113, at 1691 . In that case, the Court invalidated a social security benefits provision which disadvantaged the survivors of female workers. Only a plurality saw the scheme as discriminatory toward women. Since that time, however, a majority seems to have become adept at recognizing such discrimination against deceased workers. See Wengler v. Druggists Mut. Ins. Co., 446 U.S. 142, 152 (1980) (workers' compensation laws denying widower benefits on his wife's work-related death that are available to widows violates equal protection clause).

132. See the concurrence of Justice Stevens (joined by Burger), and the partial concurrence of Justices Marshall, Brennan and Blackmun in City of Cleburne v. Cleburne Living Center, 105 S. Ct. 3249 (1985) (zoning ordinance violative of equal protection clause as applied to prohibition of group home for mentally retarded).

133. Id. The Cleburne plurality seems to hold that in order for classification to command higher scrutiny, the petitioners must first show that the classification at issue can never be justified. $105 \mathrm{~S}$. Ct. at 3255. Thus, the irrelevance of a classification must be demonstrated before the classification can be shown to be irrelevant. Thus, the Supreme Court has illustrated the truth in MacKinnon's reductio ad absurdum treatment of the differences approach: In order to achieve equality you must first be equal. As unfortunate as it may be, the Cleburne state of affairs smacks to me more of confusion than ideology.

134. 417 U.S. 484 (1974). As Sylvia Law aptly puts it, criticizing Geduldig has become "a cot- 
(that no discrimination exists if pregnant women and pregnant men are treated the same) is not that the Supreme Court used the wrong legal standard. The problem was much more serious: It was that our highest court cavalierly allowed California to disadvantage women with respect to their reproductive capabilities. Our highest court endorsed a modern version of a centuries-old method of domination.

We must never forget Geduldig. Our Supreme Court got away with it because we allowed the question of pregnancy to be sequestered in our own minds from the question of domination. In our search for a liberal resolution, the real issue remained invisible, and our critique came dangerously close to consent. Our objections can no longer be oblique, for then they are lost. Keeping dissent hidden is an ancient tactic which renders the dissent trivial, abnormal, and disconnected from its roots. Due to the distribution of women in society, this has particularly been the case with feminism. Because each new feminist work or insight appears as if from nowhere, "each contemporary feminist theorist [is] attacked or dismissed ad feminam, as if her politics were simply an outburst of personal bitterness or rage."13s Trust we must have that we can describe the issues; empowered we must be when our trust is violated.

The proposed inequality standard will not take root overnight. Developments in feminist theory take decades to manifest themselves in law. ${ }^{136}$ But it will happen; the difficulty of the process must not stop us from demanding that change, or from continuing the tradition that makes it possible.

\section{Feminist Method Revisited}

The term "feminist jurisprudence" disturbs people. That is not surprising, given patriarchy's convenient habit of labeling as unreliable any approach that admits to be interested, and particularly given the historic $a$

tage industry." Law, supra note 13, at 983 \& n.107 (citing more than two dozen articles critical of decision).

135. A. Rich, supra note 61, at 11. Similarly, Virginia Woolf argued: "[M]asterpieces are not single and solitary births; they are the outcome of many years of thinking in common, or thinking by the body of the people, so that the experience of the mass is behind the single voice." V. Woolf, supra note 60, at 68-69. Woolf believed that the lack of recoverable tradition behind nineteenth century women writers was the single greatest obstacle they faced. Id. at 79.

136. An example is American Booksellers Ass'n., Inc. v. Hudnut, 771 F. 2d 323 (7th Cir. 1985), affd, $106 \mathrm{~S}$. Ct. 1172 (1986). In the opinion invalidating the Indianapolis pornography ordinance, the Seventh Circuit carries on a rhetorical (and usually unfair) discussion with Catharine MacKinnon, one of the drafters of the ordinance. Id. at 325, 328-30 (citing MacKinnon, Pornography, Civil Rights, and Speech, 20 HARv. C.R.-C.L. L. REv. 1 (1985)). The Seventh Circuit even accepts the premises of the legislation. 771 F. 2d at 329. From a broader perspective, however, the feminist critique of liberal assumptions about the nature of "freedom" has existed in principle since the publication of The Second Sex in 1952, S. DE BEAUvorr, supra note 53, and explicitly since the publication The Dialectic of Sex in 1970, S. Firestone, The Dialecric of Sex (1970). 
priori invalidation of women's experience. That longstanding invalidation also causes women, including feminist women, to be reluctant to make any claims beyond the formal reach of liberalism. Further, we are taught to ascribe the legal system's successes to the principle of detachment.

In the understandable rush to render feminism acceptable in traditional terms, it is sometimes suggested that we ought to advertise our insight as a revival of the Legal Realism of the 1930 's. ${ }^{137}$ We are surely indebted to the Realists for their convincing demonstration that the law could not be described, as the positivists had hoped, as a scientific enterprise, devoid of moral or political content. The Realists' description of the influence of morality, economics, and politics upon law is the first step in developing an antidote for legal solipsism. In the end, however, the Realists did not revolutionize the law but merely expanded the concept of legal process. ${ }^{138}$ The Realists did not press their critique deeply enough; they did not bring home its implications. In the face of their failure, the system has clung even more desperately to objectivity and neutrality. "[T] Realists was much like the role that Carlyle pronounced for Matthew Arnold: 'He led them into the wilderness and left them there.' "139

Feminism now faces the charge leveled at Realism, that it destroys the citadel of objectivity and leaves nothing to legitimate the law. Our response to this state of affairs begins with an insight rot exclusive to feminist thought: The law must finally enter the twentieth century. The business of living and progressing within our disciplines requires that we give up on "objective" verification at various critical moments, such as when we rely upon gravity, ${ }^{140}$ or upon the existence of others, ${ }^{141}$ or upon the

137. It is important to cultivate these analogies, especially insofar as there are lawyers out there who wonder what ever happened to legal realism and are dissatisfied with Critical Legal Studies as a successor. To explore where feminism differs from realism (and for that matter, from CLS) is a way to get at the most elusive and crucial aspects of the theory.

138. See, e.g., Cohen, Transcendental Nonsense and the Functional Approach, 35 Colum. L. REv. 809, 812 (1935):

When the vivid fictions and metaphors of traditional jurisprudence are thought of as reasons for decisions, rather than poetical or mnemonic devices for formulating decisions reached on other grounds, then the author, as well as the reader, of the opinion or argument, is apt to forget the social forces which mold the law and the social ideals by which the law is to be judged. Thus it is that the most intelligent judges in America can deal with a concrete practical problem of procedural law and corporate responsibility without any appreciation of the economic, social, and ethical issues which it involves.

See also G. Gilmore, The AGES OF AMERICAN LAw 87 (1977) (arguing that the realist "revolution may have been merely a palace revolution, not much more than a changing of the guard.").

139. R. Stevens, Law School: Legal. Education in America from the 1950s to the 1980 s, at 156 (1983).

140. See T. KuHn, The Structure of Scientific Revolutions 108 (2d ed. 1970) (abandonment by eighteenth-century scientists of attempt to explain gravity reflected "neither a decline nor a raising of standards, but ... the adoption of a new paradigm").

141. See L. WITTGENSTEIN, supra note 66. One of the favorite targets of Wittgenstein's war on philosophical muddles was metaphysical solipsism, which maintains that the self of the thinker is the whole of reality; the external world and other persons have no independent existence. This argument 
principle of verification itself. Feminism insists upon epistemological and psychological sophistication in law: Jurisprudence will forever be stuck in a post-realist battle of subjectivities, with all the discomfort that has represented, until we confront the distinction between knowing subject and known object.

Feminist method is exemplary of that confrontation. The physics of relativity and quantum mechanics demonstrate that nature is on our side: Nature itself has begun to evince a less hierarchical structure, a multidirectional flow of authority which corroborates our description of perception. ${ }^{142}$ We warmly embrace the uncertainty inherent in that perceptual model, recognizing the humanity, and indeed, the security, in it. ${ }^{143}$ And because we do not separate the observer from the observed, "[f]eminism is the first theory to emerge from those whose interest it affirms." 144 Feminist method proceeds through consciousness raising. The results of consciousness raising cannot be verified by traditional methods, nor need they be. ${ }^{145} \mathrm{We}$ are therefore operating from within an epistemological framework which denies our power to know. This is an inherently transformative process: It validates the experience of women, the major content of which has been invalidation. ${ }^{148}$

Feminism criticizes this male totality without an account of our capacity to do so or to imagine or realize a more whole truth. Femi-

commonly asserts that I cannot be certain of your existence because I cannot experience your sensations; I cannot, for example, "know" your "pain." Beginning from the perspective of how people actually use language, Wittgenstein demonstrated that such an assertion merely evinces confusion about the grammar of the word "know" (id. § 246, at 89) and the word "pain" (id. §§ 293, 303, 384, at $100,102,118$ ). Thus, it makes sense to say "I feel my pain," or "I know your pain" (id. $\S 246$, at 89), but to maintain that I know my pain and don't know yours makes no more sense than to say, "Someone is in pain-I don't know who!" (id. \$§ 407-408, at 123).

142. See E. KELLER, supra note 48, at 169-71, 175-76.

143. Feminists are probably more comfortable with the uncertainty than are physicists. See id. at 139-49 (chapter entitled Cognitive Repression in Contemporary Physics).

144. MacKinnon, An Agenda for Theory, supra note 16, at 543. Because feminism emerges from women themselves, we can largely avoid the old quandary of whether revolutionary consciousness arises from the masses or must be prompted by a revolutionary elite. See M. BARRETT, WOMEN's Oppression Today: Problems in Marxist Feminist Analysis 88-98 (1980); V. Lenin, What Is To BE DONE?, 29-53 (1969 ed.). That is not to say that the women's movement has not suffered from elitism. It has, but not due to a theoretical failure; feminism is not plagued with a theory that is "acontextual". See MacKinnon, An Agenda for Theory, supra note 16, at 527 n.23.

145. J.L. Austin has explained the relationship between certainty and confidence in memories and past discernment. In many situations, "knowing" consists in seeing or sensing some feature or features which we are sure are similar to something noted and named before in our experience. "But, this that we see, or otherwise sense, is not necessarily describable in words, still less describable in detail, and in non-committal words, and by anybody you please." J. AUSTIN, Philosophical PAPERs 84-85 (3d ed. 1979) (emphasis in original). Austin stresses the importance of being in a position to know: "[I]f we have had the necessary experience, then we can, in favorable current circumstances, say we know ...."Id. at 104 (emphasis in original).

146. See MacKinnon, An Agenda for Theory, supra note 16, at 536; MacKinnon, Toward Feminist Jurisprudence, supra note 16 , at 638 . 
nism affirms women's point of view by revealing, criticizing, and explaining its impossibility. This is not a dialectical paradox. It is a methodological expression of women's situation. . . . Women's situation offers no outside to stand on or gaze at, no inside to escape to, too much urgency to wait, no place else to go, and nothing to use but the twisted tools that have been shoved down our throats. If feminism is revolutionary, this is why. ${ }^{147}$

Consciousness raising is a vivid expression of self-creation and responsibility. To Wittgenstein's insight that perceptions have meaning only in the context of experience, feminism would add that perceptions have meaning only in the context of an experience that matters. Consciousness raising means that dramatic eye-witness testimony is being given; it means, more importantly, that women now have the confidence to declare it as such. We have an alternative to relegating our perception to the realm of our own subjective discomfort. Heretofore, the tried and true scientific strategy of treating non-conforming evidence as mistaken worked in the legal system. But when that evidence keeps turning up, when the experience of women becomes recalcitrant, it will be time to treat that evidence as true. ${ }^{148}$

The foundations of the law will not thereby crumble. Though feminism rejects the notion that for a legal system to work, there have to be "objective" rules, we admit that legality has (or should have) certain qualities. There must be something reliable somewhere, there must be indicia of fairness in the system, but neither depends on objectivity. Rather, we need to discard the habit of equating our most noble aspirations with objectivity and neutrality. We need at least to redefine those terms, and probably to use others, to meet our very serious responsibilities.

My admission that feminism is result-oriented does not import the renunciation of all standards. In a system defined by constitutional norms

147. MacKinnon, Toward Feminist Jurisprudence, supra note 16, at 637, 639.

148. MacKinnon illustrates with reference to rape. Rape law has assumed that a single, objective state of affairs existed: A "rape" occurred or it didn't; consent was given or it wasn't. In fact, however, the reality is often split-"a woman is raped but not by a rapist," id. at 654 -and in focusing on the accused's state of mind, the law concludes that the rape did not happen. The dilemma here involves more than questions of legal process. Deciding what presumptions should apply then requires a reexamination of law's presuppositions about sexuality itself, and then a decision as to what conditions of sexuality the law should enforce. The choice may come down to one between protecting the likelihood that men will mistakenly infer consent, on one hand, and encouraging women's access to the world without fear, on the other. According to MacKinnon,

Whose subjectivity becomes the objectivity of 'what happened' is a matter of social meaning, that is, it has been a matter of sexual politics. One-sidedly erasing women's violation or dissolving the presumptions into the subjectivity of either side are alternatives dictated by the terms of the object/subject split, respectively. These are alternatives that will only retrace that Id.

split until its terms are confronted as gendered to the ground. 
such as equality, we need standards to help us make connections among norms, and to help us see "family resemblances"149 among instances of domination. Standards, however, are not means without ends: They never have and never can be more than working hypotheses. ${ }^{180}$ Just as it would be shocking to find a case that said, "the petitioner wins though she satisfied no criteria," so it must ultimately be wrong to keep finding cases that say, "petitioner loses though the criteria are indefensible." In legal situations, a case is either conformed to a standard or the standard is modified with justification. That justification should not be that "we like the petitioner's facts better;" rather, it is that "on facts such as these, the standard doesn't hold up."

The feminist approach takes justification seriously; it is a more honest and efficient way to achieve legitimacy. The feminist legal standard for equality is altogether principled in requiring commitment to finding the moral crux of matters before the court. The feminist approach will tax us. We will be exhausted by bringing feminist method to bear. Yet we must force law makers and interpreters to hear that which they have been well trained to ignore. We will have to divest ourselves of our learned reticence, debrief ourselves every day. We will have to trust ourselves to be able to describe life to each other-in our courts, in our legislatures, in our emergence together.

149. L. Wrttgenstein, supra note $66, \S 67$, at 32 .

150.

No systematic thought has made progress apart from some adequately general working hypothesis, adapted to its special topic. Such an hypothesis directs observation, and decides upon the mutual relevance of various types of evidence. In short, it prescribes method. To venture upon productive thought without such an explicit theory is to abandon oneself to the doctrines derived from one's grandfather.

A. WhItEhEAD, AdVENTURES of IdEAS 286 (1933). 
